\title{
PENGEMBANGAN MEDIA PEMBELAJARAN APLIKASI PETA AKUNTANSI (TAKSI) BERBASIS ANDROID PADA MATERI SIKLUS AKUNTANSI PERUSAHAAN JASA
}

\section{DEVELOPMENT OF LEARNING MEDIA USING ANDROID-BASED APPLICATION PETA AKUNTANSI (TAKSI) ON ACCOUNTING CYCLE OF SERVICE ENTERPRISE MATERIAL}

Oleh:

Faras Dwi Izzati

Prodi Pendidikan Akuntansi Universitas Negeri Yogyakarta farasizzati@gmail.com

\section{Sumarsih}

Staf Pengajar Jurusan Pendidikan Akuntansi Universitas Negeri Yogyakarta

\begin{abstract}
Abstrak
Penelitian ini bertujuan untuk: (1) mengembangkan Media Pembelajaran Aplikasi Peta Akuntansi (TAKSI) Berbasis Android pada materi Siklus Akuntansi perusahaan jasa untuk siswa kelas X Akuntansi SMK Negeri 1 Slawi; (2) mengetahui kelayakan aplikasi Peta Akuntansi (TAKSI) berbasis Android; (3) mengetahui penilaian siswa terhadap aplikasi Peta Akuntansi (TAKSI) berbasis Android; (4) mengetahui efetivitas penggunaan aplikasi Peta Akuntansi (TAKSI) berbasis Android. Penelitian ini merupakan penelitian pengembangan (Research and Development) dengan mengikuti model pengembangan ADDIE. Hasil penelitian menunjukan: (1) media pembelajaran aplikasi Peta Akuntansi (TAKSI) dikembangkan melalui 5 tahapan yaitu: a) Analysis; b) Design; c) Development; d) Implementation; dan e) Evaluation. (2) media pembelajaran aplikasi Peta Akuntansi (TAKSI) ini layak digunakan berdasarkan penilaian: a) Ahli materi diperoleh persentase 96,25\% (Sangat Layak), b) Ahli media diperoleh persentase 82,30\% (Sangat Layak), dan c) Praktisi Pembelajaran Akuntansi diperoleh persentase $89,42 \%$ (Sangat Layak). (3) penilaian siswa terhadap media pada ujicoba perorangan diperoleh persentase 99,58\% (Sangat Layak), ujicoba kelompok kecil diperoleh persentase 91,67\% (Sangat Layak), dan penelitian lapangan diperoleh persentase 91,80\% (Sangat Layak). (4) Berdasarkan analisis peningkatan hasil pretest dan posttest dengan gain skor, Media Pembelajaran Apliaksi Peta Akuntansi (TAKSI) Berbasis Andoid efektif digunakan.
\end{abstract}

Kata kunci: Media Pembelajaran, Peta Akuntansi (TAKSI), Android, ADDIE.

\section{Abstract}

This research aims to: (1) develop Learning Media using Android-Based Application Peta Akuntansi (TAKSI) on Accounting Cycle of Service Enterprise material for $10^{\text {th }}$ grade accounting students of SMK Negeri 1 Slawi; (2) Determine the feasibility android-based application Peta Akuntansi (TAKSI); (3) Determine the assessment of students to android-based application Peta Akuntansi (TAKSI); (4) Determine the effectiveness of android-based application Peta Akuntansi (TAKSI). This research uses the approach of Research and Development following the ADDIE. The results showed: (1) learning media application Peta Akuntansi (TAKSI) development through 5 phases, theye were: a) Analysis; b) Design; c) Development; d) Implementation; dan e) Evaluation. (2) learning media application Peta Akuntansi (TAKSI) was fit for use as by assessment: a) matter expert, obtained percentage of 96,25\% (very feasible) b) Media expert, obtained percentage of 82,30\% (very feasible), 
c) Accounting teacher, obtained percentage of 89,42\% (very feasible), 3) Student assessment to media on Individual testing, obtained percentage of 99,58\% (very feasible), Small Group testing, obtained percentage of $91,67 \%$ (very feasible), and field-research, obtained percentage of 91,80\% (very feasible), (4) Based on analysis of the increasing value in the pretest and posttest with gain skor Learning Media using Android-Based Application Peta Akuntansi (TAKSI) effective to use as an Accounting learning media.

Keyword: Learning Media, Peta Akuntansi (TAKSI), Android, ADDIE.

\section{PENDAHULUAN}

Perkembangan teknologi informasi semakin pesat dan sudah tidak asing lagi bagi kehidupan manusia. Teknologi informasi yang diciptakan dari waktu ke waktu memberikan banyak manfaat dalam kegiatan manusia. Salah satu pemanfaatannya adalah menjadikan teknologi informasi sebagai media pembelajaran. Dengan menjadikan teknologi informasi sebagai media pembelajaran dalam proses pembelajaran diharapkan dapat meningkatkan kualitas pendidikan.

Dunia pendidikan tidak terlepas dari proses pembelajaran yang meliputi guru, siswa, dan lingkungan pembelajaran yang saling terkait satu sama lain dalam rangka tercapainya tujuan pembelajaran. Hal ini merupakan salah satu faktor penunjang tercapainya tujuan pembelajaran. Media merupakan salah satu faktor penunjang tercapainya tujuan pembelajaran, hal ini berkaitan dengan penggunaan media yang tepat dan bervariasi dalam proses pembelajaran. Salah satu cara menciptakan pembelajaran yang menyenangkan yaitu dengan penggunaan media pembelajaran. Menurut Rossi dan Briedle (1996) dalam Wina Sanjaya (2014: 163) media pembelajaran adalah semua alat dan bahan yang dapat digunakan untuk mencapai tujuan pendidikan. Seorang pendidik pasti akan menyiapkan media pembelajaran sebagai penunjang dalam proses pembelajaran seperti power point, video pembelajaran, dan sebagainya. Media pembelajaran saat ini perlu adanya inovasi agar dapat mengikuti perkembangan ilmu pengetahuan dan teknologi, apabila dibandingkan dengan media pembelajaran buku teks Akuntansi atau Modul Akuntansi yang pada umumnya tebal, peserta didik lebih memilih menggunakan media yang berbasis teknologi yang terkesan praktis. Pemanfaatan media pembelajaran dapat diterapkan di semua mata pelajaran termasuk Akuntansi. Salah satu standar kompetensi Akuntansi di kelas $\mathrm{X}$ adalah Siklus Akuntansi Perusahaan Jasa. Berdasarkan wawancara yang dilakukan pada tanggal 6 Oktober 2016 guru Akuntansi SMK Negeri 1 Slawi mengatakan bahwa pada standar kompetensi Siklus Akuntansi Perusahaan Jasa terdapat materi yang dirasa cukup sulit disampaikan hanya dengan menggunakan cara pembelajaran yang konvensional atau ceramah dan media yang terbatas, materi tersebut adalah tahap pengikhtisaran dan pelaporan Siklus Akuntansi Perusahaan Jasa.

Perkembangan teknologi mobile saat ini begitu pesat, salah satu perangkat mobile yang saat ini sudah umum digunakan adalah smartphone, $70 \%$ peserta didik kelas $\mathrm{X}$ Akuntansi di SMK N 1 Slawi menggunakan smartphone Android. Dalam hal ini diharapkan peserta didik dapat memanfaatkan smartphone tersebut sebagai penunjang dalam kegiatan pembelajaran. Pengembangan media pembelajaran menggunakan smartphone disebut dengan Mobile Learning. Mobile Learning dapat memudahkan pengguna untuk mengakses konten pembelajaran di mana saja dan kapan saja, tanpa harus mengunjungi suatu tempat tertentu. Mobile Learning berhubungan dengan mobilitas belajar, dalam arti pelajar 
semestinya mampu terlibat dalam kegiatan pendidikan tanpa harus melakukan di sebuah lokasi fisik tertentu. (Panji Wisnu Wirawan, 2011:22-23).

Perangkat mobile yang digunakan dalam mobile learning antara lain PDA, smartphone, laptop, dan tablet PC. Dalam hal ini mobile learning memungkinkan siswa dapat mengakses materi maupun informasi yang berkaitan dengan pembelajaran kapanpun dan di manapun. Di SMK N 1 Slawi belum ada media pembelajaran yang memanfaatkan telephone seluler/smartphone. Para siswa masih banyak yang menggunakan laptop dan buku sebagai menunjang pembelajaran di sekolah. Siswa SMK N 1 Slawi sudah banyak yang menggunakan smartphone Android.

Salah satu pertimbangan dalam mengembangkan smartphone menjadi media pembelajaran $m$-learning adalah basis sistem operasi yang digunakan. Sistem operasi yang paling banyak digunakan di smartphone adalah Android. Lembaga riset Gartner menilai popularitas sistem Android akan terus melaju jauh di atas komperitornya seperti iOS (iPhone Operating System) produsen Apple, Blackberry (RIM), Windows Mobile (Microsoft) dan Symbian (Nokia) pada kuartal pertama 2011. Berdasarkan data dari IDC (International Data Corporation) pada tahun 2016 Android memegang $87,6 \%$. Market share smartphone di seluruh dunia, iPhone operating system merupakan sistem operasi dari iPhone menduduki peringkat ke dua dengan 11,7\%, disusul dengan Windows Phone di perangkat ke tiga sebesar $0,4 \%$ dan pengguna operating system yang lainya adalah $0,3 \%$.

Akuntansi merupakan salah satu mata pelajaran yang memerlukan kesabaran, kerapian, dan ketelitian. Siswa dituntut untuk selalu serius dan memperhatikan ketika proses pembelajaran berlangsung. Pada mata pelajaran Akuntansi standar kompetensi Siklus Akuntansi Perusahaan Jasa diharapkan siswa dapat memahami materi mulai dari tahap pencatatan, penggolongan, pengikhtisaran, pelaporan, jurnal penutup, neraca saldo setelah penutupan, dan jurnal pembalik. Materi ini membutuhkan pemahaman dan ketelitian dalam menghitung sehingga dibutuhkan media pembelajaran yang memotivasi dan menyenangkan bagi peserta didik. Pengembangan aplikasi berbasis Android diharapkan bisa memfasilitasi kebutuhan siswa untuk belajar di manapun dan kapanpun. Aplikasi Taksi merupakan aplikasi berbasis Android dengan mengenalkan media pembelajaran yang menarik dan menyenangkan untuk digunakan. Taksi memuat materi dan latihan soal untuk mengajak siswa agar lebih mudah mempelajari Akuntansi khususnya pada materi Siklus Akuntansi Perusahaan Jasa.

Berdasarkan observasi yang dilakukan di kelas X Akuntansi di SMK Negeri 1 Slawi yang terdiri dari 4 kelas yaitu kelas $\mathrm{X}$ Akuntansi 1, X Akuntansi 2, X Akuntansi 3 dan $\mathrm{X}$ Akuntansi 4 dengan jumlah siswa masing masing kelas sebanyak 34 siswa, secara keseluruhan sudah memiliki telepon seluler masing-masing dan mayoritas menggunakan smartphone Android, di SMK Negeri 1 Slawi khususnya kelas $\mathrm{X}$ Akuntansi belum ada media pembelajaran yang memanfaatkan telepon seluler, dan siswa yang menggunakan smartphone Android tidak memiliki aplikasi yang berkaitan dengan mata pelajaran Akuntansi. Para siswa masih banyak yang menggunakan laptop dan buku teks manual untuk menunjang pembelajaran di sekolah. Terkadang penerapan metode konvensional atau ceramah, tanya jawab dan diskusi membuat siswa cenderung kurang tertarik dan bosan. Melihat potensi ini, pengembangan media pembelajaran dengan memanfaatkan telepon seluler adalah dengan membuat aplikasi yang ditujukan untuk smartphone Android karena operating system Android adalah sebuah sistem yang paling praktis dan banyak digunakan pada smartphone serta harganya yang terjangkau.

Berdasarkan uraian di atas penulis termotivasi untuk mengembangkan media 
pembelajaran aplikasi Peta Akuntansi (TAKSI) Berbasis Android pada materi Siklus Akuntansi Perusahaan Jasa untuk Siswa Kelas X Akuntansi SMK Negeri 1 Slawi Tahun Ajaran 2016/2017.

\section{METODE PENELITIAN}

\section{Jenis Penelitian}

Penelitian ini merupakan riset dan pengembangan atau reseach and development $(R \& D)$. Sugiyono (2012: 407) mengemukakan bahwa $R \& D$ adalah penelitian yang digunakan untuk menghasilkan produk tertentu dan menguji keefektifan produk tersebut. Produk yang dihasilkan dapat berupa materi pelajaran, media pembelajaran, dan sistem manajemen, sedangkan menurut Endang Mulyatiningsih (2011: 161) "penelitian dan pengembangan bertujuan untuk menghasilkan media baru melalui proses pengembangan". Secara umum, penelitian dan pengembangan merupakan penelitian yang bertujuan untuk menghasilkan produk baru dan menguji keefektifan produk tersebut. Penelitian ini difokuskan pada pengembangan produk media pembelajaran aplikasi berbasis Android. Prosedur dan tahapan pengembangan penelitian ini menggunakan ADDIE yang dikembangkan oleh Dick and Carry (1996) dalam Endang Mulyatiningsih (2011:179) yaitu dengan tahapan Analysis, Design, Development or Production, Implementation or Delivery, and Evaluation.

\section{Waktu dan Tempat Penelitian}

Penelitian ini akan dilaksanakan di SMK Negeri 1 Slawi yang beralamat di Jl. KH. Agus Salim, Procot, Slawi, Kabupaten Tegal. Penelitiann dilaksanakan pada bulan Februari-Maret 2017.

\section{Subjek Penelitian}

Subjek dalam penelitian ini adalah siswa kelas 80 siswa kelas X Akuntansi SMK Negeri 1 Slawi Tahun ajaran 2016/2017 disajikan pada tabel berikut.
Tabel 1. Subjek penelitian

\begin{tabular}{|c|c|l|}
\hline Kelas & $\begin{array}{c}\text { Jumlah } \\
\text { siswa }\end{array}$ & \multicolumn{1}{|c|}{ Keterangan } \\
\hline XI AK 1 & 3 & Ujicoba perorangan \\
\hline XI AK 2 & 34 & $\begin{array}{l}\text { Penelitian lapangan } \\
\text { tidak memakai media }\end{array}$ \\
\hline XI AK 3 & 9 & $\begin{array}{l}\text { Ujicoba kelompok } \\
\text { kecil }\end{array}$ \\
\hline XI AK 4 & 34 & $\begin{array}{l}\text { Penelitian lapangan } \\
\text { memakai media }\end{array}$ \\
\hline
\end{tabular}

\section{Prosedur}

Prosedur penelitian ini mengadaptasi model pengembangan $A D D I E$, yaitu model pengembangan yang terdiri dari Analysis (analisis), Design (Desain), Development (Pengembangan), Implementation (Implementasi) dan Evaluating (Evaluasi). Menurut Endang Multyaningsih (2012:199) model ADDIE dapat digunakan untuk berbagai bentuk pengembangan produk seperti model, strategi pembelajaran, metode pembelajaran, media dan bahan ajar. Prosedur pengembangan Media Pembelajaran Aplikasi Taksi Berbasis Android sesuai dengan adaptasi model pengembangan ADDIE adalah sebagai berikut :

a. Tahap Analisis (Analysis)

Pada tahap ini, kegiatan utama adalah menganalisis perlunya pengembangan produk guna mengatasi permasalahan yang terjadi dalam pembelajaran Akuntansi. Tujuan pada tahap analisa adalah untuk mengumpulkan berbagai informasi yang relevan dengan pengembangan Media Pembelajaran Aplikasi Taksi Berbasis Android pada materi Siklus Akuntansi Perusahaan Jasa untuk siswa kelas X Akuntansi SMK Negeri 1 Slawi.

Peneliti menganalisis kurikulum dan kompetensi yang meliputi analisis terhadap Standar Kompetensi (SK) dan Kompetensi Dasar (KD) yang dimuat dalam media ini. SK yang akan dimuat adalah Memahami Siklus Akuntansi Perusahaan Jasa dengan KD tahap pengikhtisaran, tahap pelaporan, jurnal penutup, neraca saldo setelah 
penutupan, dan jurnal pembalik. Analisis instruksional merupakan penjabaran KD yang telah dipilih pada tahap analisis kompetensi menjadi indikator pembelajaran yang memungkinkan untuk disajikan dalam aplikasi Taksi.

b. Tahap Desain (Design)

Berdasarkan hasil analisis, tahap selanjutnya adalah tahap desain atau pengembangan produk yang meliputi tahap berikut :

1) Pembuatan Desain Media (Storyboard)

$\begin{array}{cr}\text { Storyboard } & \text { merupakan } \\ \text { rancangan } & \text { desain }\end{array}$
pembelajaran secara keseluruhan yang dimuat dalam aplikasi. Storyboard berfungsi untuk memudahkan dalam melakukan pengembangan media pembelajaran.

2) Menyusun Materi, Soal, dan Jawaban

Pada tahap ini ditetapkan dasar pemilihan materi, menyusun soal latihan dan jawaban yang akan dimuat dalam media pembelajaran. Materi dan soal yang dibuat harus sesuai dengan apa yang dibutuhkan oleh siswa dalam memecahkan masalah.

3) Pembuatan dan Pengumpulan background, gambar karakter, gambar icon aplikasi, dan simbolsimbol.

Background, gambar karakter, gambar icon aplikasi, dan simbolsimbol dibuat dalam format gambar .png (portable network graphics) dengan menggunakan corelDraw Graphicst Suite X6.

c. Tahap Pengembangan (Development)

1) Pembuatan Media Pembelajaran Taksi

Seluruh persiapan pada tahap sebelumnya di rangkai menjadi satu. Diawali dengan pembuatan antarmuka, pengkodean, pengujian, dan penelitian lapangan.

2) Validasi dan Revisi Ahli Materi dan Ahli Media

a) Validasi I dilakukan oleh Ahli Materi dan Ahli Media. Hasilnya berupa saran, komentar, dan masukan yang dapat digunakan sebagai dasar untuk melakukan analisis dan revisi terhadap media yang dikembangkan dan sebagai dasar untuk ujicoba media pada siswa.

b) Revisi Media I. Tahap ini media direvisi berdasarkan saran dari Ahli Materi dan Ahli Media.

c) Validasi II dilakukan oleh Praktisi Pembelajaran Akuntansi di sekolah. Hasilnya berupa saran, komentar dan masukan yang dapat digunakan sebagai dasar untuk melakukan analisis dan revisi terhadap media yang dikembangkan dan sebagai dasar untuk melakukan ujicoba media pada siswa.

d) Revisi Media II. Tahap ini media direvisi berdasarkan saran dari praktisi pembelajaran akuntansi dilakukan jika diperlukan. Revisi dilakukan sesuai dengan penilaian praktisi pembelajaran. Media hasil revisi digunakan pada tahap implementasi pada siswa.

d. Tahap Implementasi (Impplementation)

Tahap implementasi dilakukan dalam tiga tahap, yaitu:

1) Ujicoba Perorangan

Ujicoba perorangan dilakukan pada 3 orang siswa kelas $\mathrm{X}$ Akuntansi 1 SMK Negeri 1 Slawi, 
yaitu siswa yang pintar, sedang, dan kurang pintar.

2) Ujicoba Kelompok Kecil

Ujicoba kelompok kecil dilakukan pada 9 siswa kelas $\mathrm{X}$ Akuntansi 3 SMK Negeri 1 Slawi yaitu 3 siswa yang pintar, 3 siswa yang sedang, dan 3 siswa yang kurang pintar.

3) Penelitian Lapangan

Penelitian lapangan dilakukan pada 34 siswa kelas X Akuntansi 4 SMK Negeri 1 Slawi.

Berdasarkan observasi dan angket yang sudah diberikan pada seluruh siswa kelas $\mathrm{X}$ Akuntansi SMK Negeri 1 Slawi, jumlah siswa paling banyak menggunakan smarthphone Android adalah kelas X Akuntansi 4 sehingga peneliti melakukan penelitian lapangan di kelas tersebut untuk mengetahui efektivitas penggunaan Media Pembelajaran Aplikasi Taksi Berbasis Android, sedangkan siswa yang paling sedikit menggunakan smarthphone Android adalah kelas X Akuntasni 2, sehingga peneliti melakukan penelitian lapangan dengan mengetahui hasil peningkatan pretest dan posttest siswa dengan tidak memakai Media Pembelajaran Aplikasi Taksi Berbasis Android.

e. Tahap Evaluasi (Evaluation)

Tahap terakhir dalam pengembangan aplikasi ini adalah evaluasi aplikasi. Tahap ini dilakukan pengukuran ketercapaian pengembangan produk.

1) Analisis Data dari Validasi Media

Pada tahap ini dilakukan analisis data yang diperoleh dari hasil penilaian/validasi kelayakan produk oleh ahli materi, ahli media, dan praktisi pembelajaran Akuntasnsi.
2) Analisis Data Siswa

Analisis data yang diperoleh dari siswa untuk mengetahui penilaian mengenai media yang dibuat. Pada tahap ini siswa dibagikan angket menilai dan mengetahui pendapat atau respon siswa mengenai Media Pembelajaran Berupa Aplikasi Taksi Berbasis Android untuk pembelajaran Akuntansi materi Siklus Akuntansi Perusahaan Jasa.

3) Hasil Media

Pada tahap ini setelah dilakukan validasi serta revisi pada tahap sebelumnya maka diperoleh media akhir berupa aplikasi Taksi berbasis Android.

4) Efektivitas Media

Untuk mengetahui efektivitas penggunaan Media Pembelajaran Aplikasi Taksi Berbasis Android pada materi Siklus Akuntansi Perusahaan Jasa untuk siswa kelas X Akuntansi SMK Negeri 1 Slawi Tahun Ajaran 2016/2017 melalui hasil peningkatan pretest dan posttest siswa yang memakai dan tidak memakai Media Pembelajaran Aplikasi Taksi Berbasis Android.

Pada penelitian lapangan di kelas X Akuntansi 4 untuk mengetahui hasil peningkatan pretest dan posttest siswa dengan memakai Media Pembelajaran Taksi, dan di kelas X Akuntansi 2 untuk mengetahui hasil pretest dan posttest siswa dengan tidak memakai media pembelajaran aplikasi Taksi.

\section{Data, Intrumen, dan Teknik} Pengumpulan

a) Data

Data yang dikumpulkan dalam penelitian ini berupa data kualitatif dan kuantitatif. 
b) Instrumen pengumpulan data

Untuk memperoleh data tentang pengembangan Media Pembelajaran Aplikasi Peta Akuntansi (TAKSI) Berbasis Android digunakan instrumen angket. Angket diberikan kepada ahli media, ahli materi, guru (praktisi pendidikan), dan siswa. Angket berupa lembar cheklist dengan skala Likert (skala 4) dengan alternatif jawaban sangat baik, baik, tidak baik, dan sangat tidak baik.

c) Teknik Analisis Data

1. Data Kualitatif

Data kualitatif berupa saran / masukan yang diberikan oleh dosen ahli materi, dosen ahli media, praktisi pembelajar akuntansi (guru) dan siswa dianalisis secara deskriptif.

2. Data Kuantitatif

Data Kuantitatif diperoleh dari angket penilaian kelayakan media yang diberikan kepada dosen ahli materi, ahli media, guru, dan siswa. Data kelayakan aplikasi tersebut berupa data kualitatif. Untuk mendapatkan penilaian kelayakan aplikasi, maka data kualitatif tersebut kemudian dianalisis dengan langkah-langkah berikut :

a. Untuk mendapatkan kelayakan aplikasi, maka diberikan skor untuk mengkonversikan data kualitatif menjadi data kuantitatif dengan ketentuan sebagai berikut.

Tabel 2. Ketentuan pemberian skor

\begin{tabular}{|l|c|}
\hline \multicolumn{1}{|c|}{ Kategori } & $\begin{array}{c}\text { Skor Pertanyaan } \\
\text { Positif }\end{array}$ \\
\hline Sangat Baik & 4 \\
\hline Baik & 3 \\
\hline Kurang Baik & 2 \\
\hline Tidak Baik & 1 \\
\hline
\end{tabular}

b. Data yang terkumpul dianalisis dengan menghitung presentase tingkat penilaian dengan rumus :

$\frac{\sum \text { Skor yang diperoleh dari peneliti }}{\sum \text { Skor ideal seluruh item }} \times 100 \%$

Sumber : Sugiyono (2014: 95)

c. Hasil presentase tingkat penilaian yang diperoleh berupa data kuantitatif dikonversi kembali menjadi data kualitatif.

Tabel 3. Ketentuan pemberian skor

\begin{tabular}{|c|c|c|}
\hline No & Rumus & Kategori \\
\hline 1 & $100 \% \geq$ skor $\leq 81,25 \%$ & $\begin{array}{c}\text { Sangat } \\
\text { Layak }\end{array}$ \\
\hline 2 & $81,25 \% \geq$ skor $\leq 62,5 \%$ & Layak \\
\hline 3 & $62,5 \% \geq$ skor $\leq 43,75 \%$ & $\begin{array}{c}\text { Kurang } \\
\text { Layak }\end{array}$ \\
\hline 4 & $43,75 \% \geq$ skor $\leq 25 \%$ & $\begin{array}{c}\text { Tidak } \\
\text { Layak }\end{array}$ \\
\hline
\end{tabular}

d. Menentukan nilai keseluruhan Media Pembelajaran Aplikasi Taksi Berbasis Android dari ahli materi, ahli media, praktisi pembelajar akuntansi, dan siswa menjadi nilai kualitatif sesuai dengan kriteria kategori penilaian.

e. Mengetahui efektivitas penggunaan Media Pembelajaran Aplikasi Taksi Berbasis Android.

1. Menghitung rata-rata gain score terhadap kelas yang memakai media dan kelas yang tidak memakai media

$$
<\text { gain }>=\frac{\text { skor posttest }- \text { pretest }}{\text { skor maksimum }- \text { pretest }}
$$

(Meltzer, 1999: 1260)

2. Menetukan kriteria perolehan gain skor dapat dilihat pada tabel berikut: 
Tabel 4. kategori perolehan gain skor

\begin{tabular}{|c|c|c|}
\hline Batasan & Kategori & Batasan \\
\hline $\mathrm{g} \geq 0,7$ & Tinggi & $\mathrm{g} \geq 0,7$ \\
\hline $0,3 \leq \mathrm{g}<$ & Sedang & $0,3 \leq \mathrm{g}<$ \\
0,7 & & 0,7 \\
\hline $\mathrm{g}<0,3$ & Rendah & $\mathrm{g}<0,3$ \\
\hline
\end{tabular}

f. Hasil dari rata-rata nilai dan hasil dari gain score dapat menunjukkan bagaimana perbandingan peningkatan rata-rata hasil pretest dan posttest kelas yang memakai dan tidak memakai Media Pembelajaran Aplikasi Taksi Berbasis Android.

\section{HASIL PENELITIAN DAN PEM- BAHASAN}

Pengembangan Media Pembelajaran Taksi Berbasis Android ini merupakan adaptasi dan dimodifikasi dari langkahlangkah penelitian dan pengembangan model ADDIE

\section{Tahap Analisis (analysis)}

a) Analisis Kebutuhan Peserta Didik

Analisis kebutuhan diperlukan untuk menentukan masalah yang dihadapi oleh siswa dalam pembelajaran Akuntansi pada materi Siklus Akuntasni Perusahaan Jasa. Pembuatan dan pengembangan Media Pembelajaran Aplikasi Taksi Berbasis Android dapat meningkatkan kualitas proses pembelajaran dan media dapat digunakan kapan saja dan di mana saja karena sifatnya yang portable.

Selain penggunaan secara mandiri oleh siswa, media pembelajaran dapat digunakan oleh guru di kelas dengan bantuan laptop/PC dan LCD, tetapi untuk menggunakan media ini di PC/Laptop memerlukan bantuan emulator Android dan spesifikasi laptop yang mendukung karena akan sangat berpengaruh pada kelancaran untuk mengaksesnya dan emulator Android dapat diunduh dengan gratis dan mudah di internet. b) Analisis Standar Kompetensi dan Instruksional

Analisis kompetensi dan intruksional berkaitan dengan Standar Kompetensi dan Kompetensi Dasar yang akan dimuat dalam media pembelajaran. Pada tahap analisis kompetensi, dilakukan kajian terhadap kompetensi minimal yang harus dicapai siswa sesuai dengan standar isi yang ditetapkan oleh Badan Standar Nasional Pendidikan (BSNP).

Memahami Siklus Akuntansi Perusahaan Jasa dengan KD tahap pengikhtisaran, tahap pelaporan, jurnal penutup, neraca saldo setelah penutupan, dan jurnal pembalik. Analisis instruksional merupakan penjabaran KD yang telah dipilih pada tahap analisis kompetensi menjadi indikator pembelajaran yang memungkinkan untuk disajikan dalam aplikasi Taksi. Materi tahap pengikhtisaran, tahap pelaporan, jurnal penutup, neraca saldo setelah penutupan, dan jurnal pembalik sesuai dengan Standar Kompetensi (SK) memahami penyusunan Siklus Akuntansi Perusahaan Jasa

\section{Tahap Desain (design)}

a) Pembuatan desain media (storyboard)

Storyboard menggambarkan secara keseluruhan gambaran aplikasi yang akan dimuat. Storyboard berfungsi sebagai panduan seperti peta untuk memudahkan proses pembuatan media.

b) Menyusun materi, soal, dan jawaban

Pada tahap ini dikemukakan dasar pemilihan materi mengenai Siklus Akuntansi Perusahaan Jasa yaitu materi tahap pengikhtisaran, tahap pelaporan, jurnal penutup, neraca saldo setelah penutupan, dan jurnal pembalik.

c) Pembuatan dan pengumpulan background, font, gambar, dan tombol

Gambar dikombinasikan dengan beberapa gambar hasil unduhan dari beberapa sumber. Pembuatan dan 
pengkombinasian gambar dilakukan dengan menggunakan corelDraw Graphicst Suite X6, sebagian besar gambar dibuat dalam format joint photographic group (.jpg) untuk background dan portable network graphics (.png) untuk gambar icon.

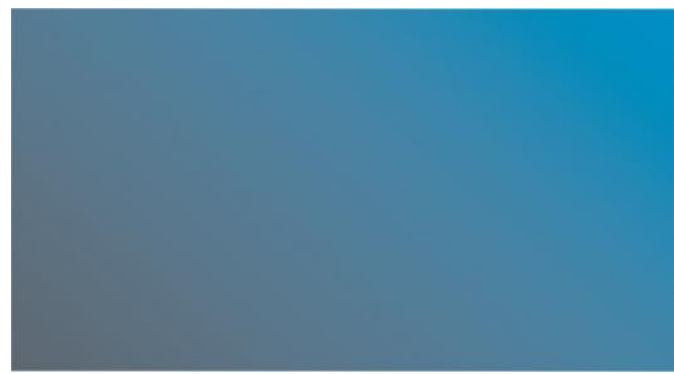

Gambar 1. Background / dasar dalam media

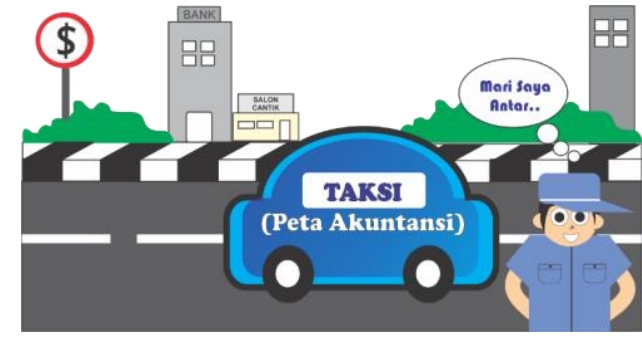

Gambar 2. Contoh desain gambar dalam media

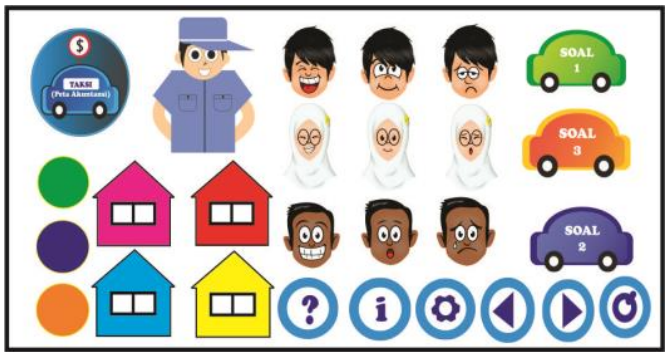

Gambar 3. Kumpulan tombol dan icon

d) Penggunaan musik dan suara

Musik dalam media peneliti menggunakan musik instrumental yang dapat menarik perhatian pengguna media pembelajaran Taksi.

Tahap Pengembangan (Development)

a) Pembuatan Media Pembelajaran Taksi
Media dibuat dengan menggunakan hardware dengan spesifikasi hard disk 320GB, RAM 4 GB, dan sistem operasi Windows 10. Seluruh komponen yang telah dipersiapkan pada tahap desain kemudian dirangkai menjadi satu kesatuan dengan menggunakan software construct2. Komponen dirangkai menjadi satu kesatuan media sesuai dengan storyboard yang sudah dibuat sebelumnya. Berikut gambaran pembuatan media

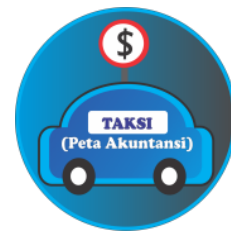

Gambar 4. Logo Aplikasi

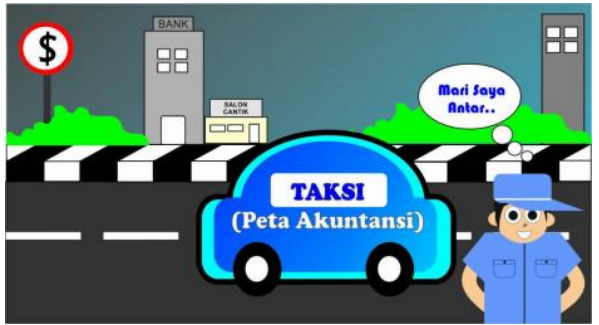

Gambar 5. Tampilan Splash Screen

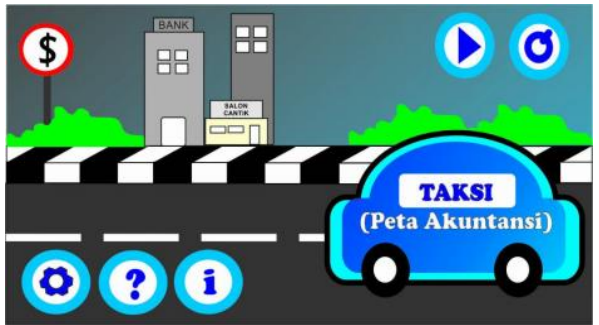

Gambar 6. Tampilan menu utama aplikasi

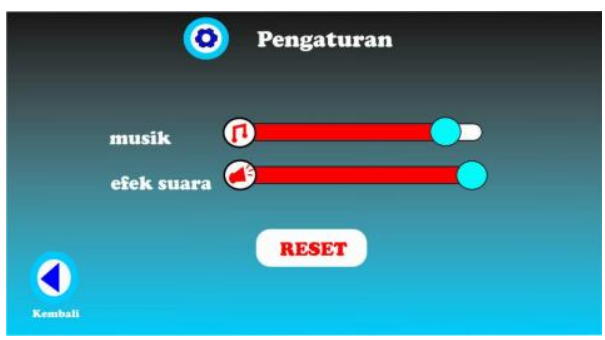


Jurnal Pendidikan Akuntansi Indonesia, Vol. XV, No. 2, Tahun 2017

Faras Dwi Izzati \& Sumarsih

$32-46$

\section{Gambar 7. Tampilan menu pengaturan}

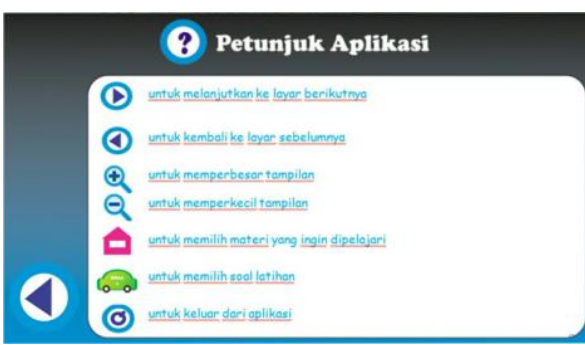

Gambar 8. Tampilan menu petunjuk aplikasi

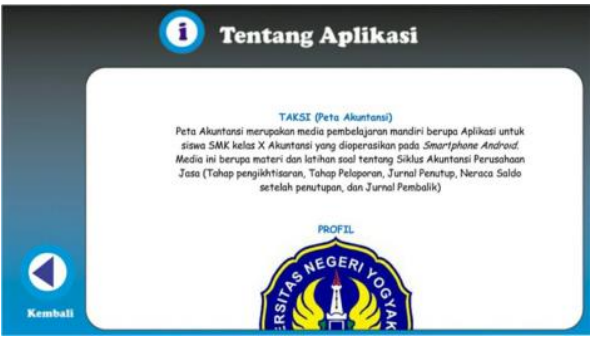

Gambar 9. Tampilan menu informasi

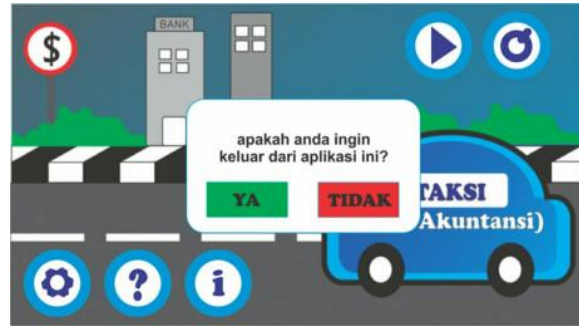

Gambar 10. Tampilan konfirmasi keluar

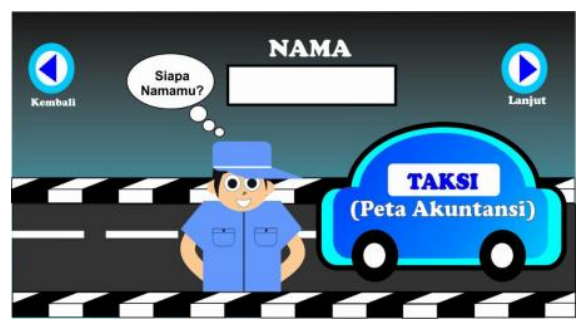

Gambar 11. Tampilan

nama

pengguna

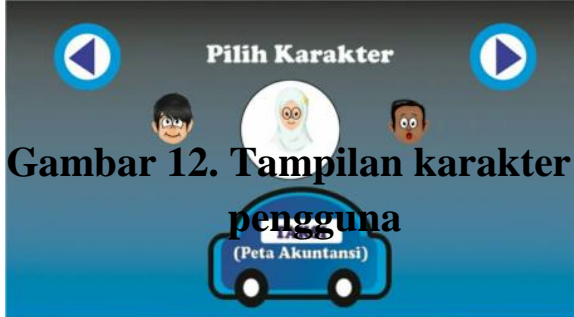

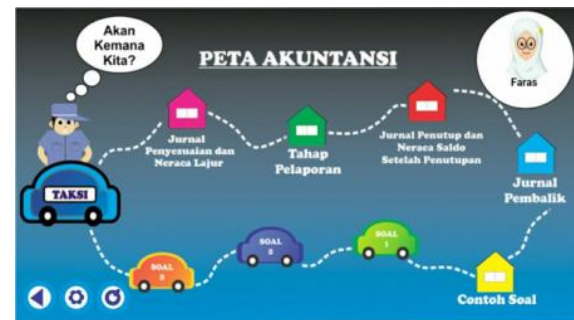

Gambar 11. Tampilan Peta Akuntansi

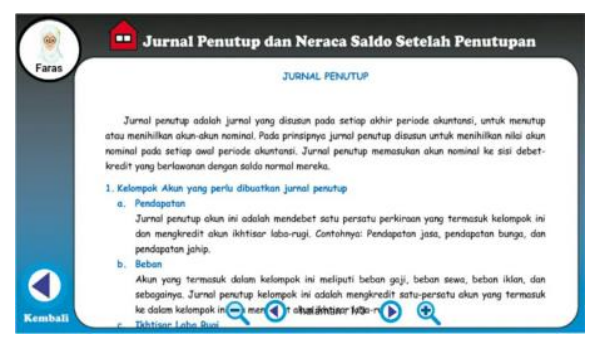

Gambar 12. Contoh tampilan materi

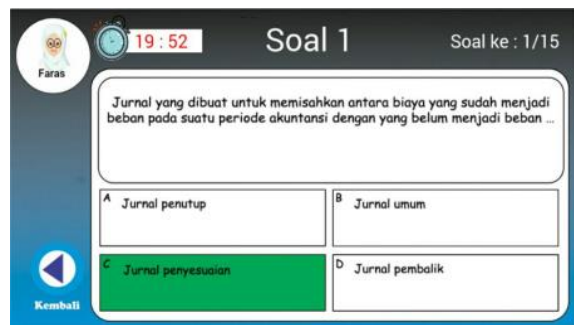

Gambar 13. Contoh tampilan soal

\section{Validasi I}

Validasi I dilakukan oleh 1 Ahli Materi dan 1 Alhi Media

1) Validasi Ahli Materi

Tabel 5. Hasil Validasi Ahli Materi

\begin{tabular}{|c|l|c|c|c|}
\hline No & $\begin{array}{c}\text { Aspek } \\
\text { Penilai } \\
\text { an }\end{array}$ & $\begin{array}{c}\text { Skor } \\
\text { yang } \\
\text { dipe- } \\
\text { roleh }\end{array}$ & $\begin{array}{c}\text { Kela- } \\
\text { yakan } \\
\%\end{array}$ & $\begin{array}{c}\text { Kate- } \\
\text { gori }\end{array}$ \\
\hline 1 & $\begin{array}{l}\text { Mate } \\
\text { ri }\end{array}$ & 36 & 100 & $\begin{array}{c}\text { Sa- } \\
\text { ngat } \\
\text { Layak }\end{array}$ \\
\hline 2 & Soal & 21 & 87,5 & $\begin{array}{c}\text { Sa- } \\
\text { ngat } \\
\text { Layak }\end{array}$ \\
\hline 3 & Bahasa & 8 & 100 & $\begin{array}{c}\text { Sa- } \\
\text { ngat } \\
\text { Layak }\end{array}$ \\
\hline 4 & $\begin{array}{l}\text { Keterla } \\
\text { k- } \\
\text { sanaan }\end{array}$ & 12 & 100 & $\begin{array}{c}\text { Sa- } \\
\text { ngat } \\
\text { Layak }\end{array}$ \\
\hline
\end{tabular}




\begin{tabular}{|c|c|c|c|}
\hline Total & 77 & 96,25 & $\begin{array}{c}\text { Sa- } \\
\text { ngat } \\
\text { Layak }\end{array}$ \\
\hline
\end{tabular}

2) Validasi Ahli Media

Tabel 6. Hasil Validasi Ahli Media

\begin{tabular}{|c|c|c|c|c|}
\hline No & $\begin{array}{c}\text { Aspek } \\
\text { Penilaian }\end{array}$ & $\begin{array}{l}\text { Skor } \\
\text { yang } \\
\text { dipe- } \\
\text { roleh }\end{array}$ & $\begin{array}{c}\text { Kela- } \\
\text { yakan } \\
\%\end{array}$ & $\begin{array}{l}\text { Kate } \\
\text {-gori }\end{array}$ \\
\hline 1 & $\begin{array}{l}\text { Rekayasa } \\
\text { perangkat } \\
\text { lunak }\end{array}$ & 41 & 85,41 & $\begin{array}{c}\text { Sa- } \\
\text { ngat } \\
\text { Laya } \\
\text { k }\end{array}$ \\
\hline 2 & $\begin{array}{l}\text { Komuni- } \\
\text { kasi } \\
\text { Visual }\end{array}$ & 38 & 79,16 & $\begin{array}{c}\text { Laya } \\
\text { k }\end{array}$ \\
\hline & Total & 79 & 82,30 & $\begin{array}{c}\text { Sa- } \\
\text { ngat } \\
\text { Laya } \\
\text { k }\end{array}$ \\
\hline
\end{tabular}

b) Revisi Media I

Berdasarkan proses validasi, dilakukan tahapan revisis media I yaitu masukan dari Ahli Materi dan Ahli Media.

1) Revisi Ahli Materi

(a) Penyajian materi ditambah, yaitu menambahkan jurnal sebelum diadakan penyesuaian.

(b) Pada contoh soal, neraca lajur dibuat dengan warna yang berbeda setiap kolomnya agar siswa mudah memahami.

2) Revisi Ahli Media

(a) Next Page Scroll tidak sesuai maka harus diganti dengan mengganti halaman scroll dimulai dari awal.

(b) Fungsi zoom belum stabil maka harus diperbaiki dengan mengganti dengan icon zoom in dan zoom out

(c) Karakter disesuaikan dengan tingkatan siswa (d) Pengaturan suara/backsound dan icon keluar bisa di atur pada halaman peta akuntansi.

c) Validasi II

Validasi II dilakukan oleh 1 Praktisi Pembelajaran Akuntansi.

Tabel 7. Hasil Validasi Praktisi Pembelajaran Akuntansi

\begin{tabular}{|c|c|c|c|c|}
\hline No & $\begin{array}{c}\text { Aspek } \\
\text { Penilai- } \\
\text { an }\end{array}$ & $\begin{array}{l}\text { Skor } \\
\text { yang } \\
\text { dipe- } \\
\text { roleh }\end{array}$ & $\begin{array}{c}\text { Kelaya- } \\
\text { kan\% }\end{array}$ & $\begin{array}{c}\text { Kate- } \\
\text { gori }\end{array}$ \\
\hline 1 & $\begin{array}{l}\text { Rekaya- } \\
\text { sa } \\
\text { perang- } \\
\text { kat lunak }\end{array}$ & 17 & 70,83 & Layak \\
\hline 2 & $\begin{array}{l}\text { Desain } \\
\text { Pembela- } \\
\text { jaran }\end{array}$ & 44 & 91,67 & $\begin{array}{c}\text { Sa- } \\
\text { ngat } \\
\text { Layak }\end{array}$ \\
\hline 3 & $\begin{array}{l}\text { Komuni- } \\
\text { kasi } \\
\text { Visual }\end{array}$ & 32 & 100 & $\begin{array}{c}\text { Sa- } \\
\text { ngat } \\
\text { Layak }\end{array}$ \\
\hline & Total & 93 & 89,42 & $\begin{array}{c}\text { Sa- } \\
\text { ngat } \\
\text { La- } \\
\text { yak }\end{array}$ \\
\hline
\end{tabular}

d) Revisi Media II

1) Penambahan waktu pada saat pengerjaan soal sehingga dapat memotivasi siswa.

2) Skor yang diperoleh diubah menjadi puluhan.

1. Tahap Implementasi (Implementation)

a) Ujicoba perorangan

Tabel 8. Hasil ujicoba perorangan

\begin{tabular}{|c|l|c|c|c|}
\hline No & $\begin{array}{c}\text { Aspek } \\
\text { Penilai- } \\
\text { an }\end{array}$ & $\begin{array}{c}\text { Skor } \\
\text { yang } \\
\text { dipe- } \\
\text { roleh }\end{array}$ & $\begin{array}{c}\text { Kelaya } \\
\text {-kan\% }\end{array}$ & $\begin{array}{c}\text { Kate- } \\
\text { gori }\end{array}$ \\
\hline 1 & $\begin{array}{l}\text { Rekaya- } \\
\text { sa } \\
\text { perang- } \\
\text { kat lunak }\end{array}$ & 60 & 100 & $\begin{array}{c}\text { Sa- } \\
\text { ngat } \\
\text { Layak }\end{array}$ \\
\hline
\end{tabular}




\begin{tabular}{|c|l|c|c|c|}
\hline 2 & $\begin{array}{l}\text { Desain } \\
\text { Pembela- } \\
\text { jaran }\end{array}$ & 84 & 100 & $\begin{array}{c}\text { Sa- } \\
\text { ngat } \\
\text { Layak }\end{array}$ \\
\hline 3 & $\begin{array}{l}\text { Komuni- } \\
\text { kasi } \\
\text { Visual }\end{array}$ & 95 & 99 & $\begin{array}{c}\text { Sa- } \\
\text { ngat } \\
\text { Layak }\end{array}$ \\
\hline & Total & $\mathbf{2 3 9}$ & $\mathbf{9 9 , 5 8}$ & $\begin{array}{c}\text { Sa- } \\
\text { ngat } \\
\text { La- } \\
\text { yak }\end{array}$ \\
\hline
\end{tabular}

\begin{tabular}{|c|l|c|c|c|}
\hline 2 & $\begin{array}{l}\text { Desain } \\
\text { Pembela- } \\
\text { jaran }\end{array}$ & 895 & $\mathbf{9 4 , 0 1}$ & $\begin{array}{c}\text { Sa- } \\
\text { ngat } \\
\text { Layak }\end{array}$ \\
\hline 3 & $\begin{array}{l}\text { Komuni- } \\
\text { kasi } \\
\text { Visual }\end{array}$ & 980 & $\mathbf{9 0 , 0 7}$ & $\begin{array}{l}\text { Sa- } \\
\text { ngat } \\
\text { Layak }\end{array}$ \\
\hline & Total & $\mathbf{2 4 9 7}$ & $\mathbf{9 1 , 8 0}$ & $\begin{array}{l}\text { Sa- } \\
\text { ngat } \\
\text { La- } \\
\text { yak }\end{array}$ \\
\hline
\end{tabular}

b) Ujicoba kelompok kecil

2. Tahap Evaluation (Evaluasi)

Tabel 9. Hasil ujicoba kelompok kecil

\begin{tabular}{|c|c|c|c|c|}
\hline No & $\begin{array}{c}\text { Aspek } \\
\text { Penilai- } \\
\text { an }\end{array}$ & $\begin{array}{c}\text { Skor } \\
\text { yang } \\
\text { dipero- } \\
\text { leh }\end{array}$ & $\begin{array}{c}\text { Kela- } \\
\text { yakan } \\
\%\end{array}$ & $\begin{array}{c}\text { Kate- } \\
\text { gori }\end{array}$ \\
\hline 1 & $\begin{array}{l}\text { Rekaya- } \\
\text { sa } \\
\text { perang- } \\
\text { kat lunak }\end{array}$ & 170 & 94 & $\begin{array}{c}\text { Sa- } \\
\text { ngat } \\
\text { Layak }\end{array}$ \\
\hline 2 & $\begin{array}{l}\text { Desain } \\
\text { Pembela- } \\
\text { jaran }\end{array}$ & 235 & 93,25 & $\begin{array}{l}\text { Sa- } \\
\text { ngat } \\
\text { Layak }\end{array}$ \\
\hline & $\begin{array}{l}\text { Komuni- } \\
\text { kasi } \\
\text { Visual }\end{array}$ & 255 & 88,50 & $\begin{array}{l}\text { Sa- } \\
\text { ngat } \\
\text { Layak }\end{array}$ \\
\hline \multicolumn{7}{|l}{ Total } & $\mathbf{6 6 0}$ & $\mathbf{9 1 , 6 7}$ & $\begin{array}{l}\text { Sa- } \\
\text { ngat } \\
\text { Layak }\end{array}$ \\
\hline
\end{tabular}

Ujicoba kelompok kecil memberikan revisi pada media pembelajaran, yaitu pada pengaturan musik ditambah dengan

c) Penelitian lapangan

Tabel 10. Hasil penelitian lapangan

\begin{tabular}{|c|l|c|c|c|}
\hline No & $\begin{array}{c}\text { Aspek } \\
\text { Penilai- } \\
\text { an }\end{array}$ & $\begin{array}{c}\text { Skor } \\
\text { yang } \\
\text { dipero- } \\
\text { leh }\end{array}$ & $\begin{array}{c}\text { Kela- } \\
\text { yakan } \\
\%\end{array}$ & $\begin{array}{c}\text { Kate- } \\
\text { gori }\end{array}$ \\
\hline 1 & $\begin{array}{l}\text { Rekaya- } \\
\text { sa } \\
\text { perang- } \\
\text { kat lunak }\end{array}$ & 622 & $\mathbf{9 1 , 4 7}$ & $\begin{array}{c}\text { Sa- } \\
\text { ngat } \\
\text { Layak } \\
\end{array}$ \\
\hline
\end{tabular}

a) Analisis Data dari Validasi Media

Pada tahap ini dilakukan analisis data yang diperoleh dari hasil penilaian/validasi kelayakan produk oleh Ahli Materi, Ahli Media dan Praktisi Pembelajaran Akuntansi.

b) Analisis Data Siswa

Pada tahap ini dilakukan analisis data yang diperoleh siswa untuk mengetahui pendapat/penilaian siswa terhadap kelayakan media.

c) Hasil Media

Pada tahap ini setelah dilakukan validasi serta revisi pada tahap sebelumnya maka diperoleh media akhir berupa aplikasi Taksi berbasis Android.

d) Efektivitas Media

1) Hasil peningkatan Pretest dan posttest kelas X Akuntansi 4

Tabel 11. Hasil pretest dan posttest $X$ AK 4

\begin{tabular}{|l|c|c|}
\hline Keterangan & Pretest & Posttest \\
\hline Jumlah siswa & 34 & 34 \\
\hline Rata-rata & 80.11 & 87.94 \\
\hline Nilai tertinggi & 91.5 & 96.5 \\
\hline $\begin{array}{l}\text { Nilai } \\
\text { terendah }\end{array}$ & 65.5 & 80 \\
\hline Skor Ideal & 100 & 100 \\
\hline
\end{tabular}

Perhitungan rata-rata gain skor kelas $\mathrm{X}$ Akuntansi 4 adalah sebagai berikut:

$$
<g>=\frac{87.94-80.11}{100-80.11}
$$




$$
\begin{gathered}
=\frac{7.82}{19.89} \\
=0.4 \text { atau } 40 \%
\end{gathered}
$$

Berdasarkan perhitungan di atas diperoleh hasil peningkatan rata-rata nilai pretest dan posttest pada kelas yang menggunakan Media Pembelajaran Aplikasi Taksi Berbasis Android yaitu kelas X Akuntansi 4 dengan gain skor yang diperoleh adalah 0,4 atau $40 \%$ berada dalam kategori $0,3 \leq \mathrm{g}<0,7$ yang dikategorikan sedang.

2) Hasil peningkatan Pretest dan posttest kelas X Akuntansi 4

Tabel 11. Hasil pretest dan posttest $X$ AK 2

\begin{tabular}{|l|c|c|}
\hline Keterangan & Pretest & Posttest \\
\hline Jumlah siswa & 34 & 34 \\
\hline Rata-rata & 85.36 & 89.64 \\
\hline Nilai tertinggi & 93.50 & 100 \\
\hline $\begin{array}{l}\text { Nilai } \\
\text { terendah }\end{array}$ & 80 & 81.50 \\
\hline Skor Ideal & 100 & 100 \\
\hline
\end{tabular}

Perhitungan rata-rata gain skor kelas $\mathrm{X}$ Akuntansi 2 adalah sebagai berikut:

$$
\begin{gathered}
<g>=\frac{89.64-85.36}{100-85.36} \\
=\frac{4.28}{14.64} \\
=0.3 \text { atau } 30 \%
\end{gathered}
$$

Berdasarkan perhitungan di atas diperoleh hasil peningkatan rata-rata nilai pretest dan posttest pada kelas yang tidak menggunakan Media Pembelajaran Aplikasi Taksi Berbasis Android yaitu kelas X Akuntansi 2 dengan gain skor yang diperoleh adalah 0,3 atau $30 \%$ berada dalam kategori $0,3 \leq \mathrm{g}<0,7$ yang dikategorikan sedang.
Secara keseluruhan dari ketiga tahap penilaian yang di lakukan oleh Ahli Materi, Ahli Media dan Praktisi Pembelajaran Akuntansi diperoleh hasil kelayakan 88,92\% yang masuk dalam kategori Sangat Layak, dan persentase hasil penilaian media pembelajaran pada penelitian lapangan di kelas X Akuntansi 4 sebesar 91,80\%.

Penelitian lapangan dalam kategori sangat layak. Kemudian pada peningkatan hasil pretest dan posttest kelas X Akuntansi 4 termasuk dalam kategori sedang, rata-rata nilai dan hasil dari gain score siswa yang memakai media memperoleh kriteria yang sama dengan yang tidak memakai media. Dapat disimpulkan bahwa Aplikasi Taksi Berbasis Android sangat layak dan cukup efektif digunakan sebagai media pembelajaran.

\section{SIMPULAN DAN SARAN Simpulan}

Berdasarkan analisis data dan pembahasan di bab IV, maka dapat disimpulkan

a. Pengembangan Media Pembelajaran Aplikasi Taksi Berbasis Android pada materi Siklus Akuntansi Perusahaan Jasa menggunakan model pengembangan $A D D I E$ yaitu Analysis (Analisis), Design (Desain), Development (Pengembangan), Implementation (Implementasi), dan Evaluation (Evaluasi).

b. Kelayakan Media Pembelajaran Aplikasi Taksi Berbasis Android pada materi Siklus Akuntansi Perusahaan Jasa berdasarkan penilaian Ahli Materi diperoleh presentase sebesar 96,25\% yang termasuk pada kategori sangat layak, Ahli Media diperoleh presentase sebesar $82,30 \%$ yang termasuk kategori sangat layak, dan Praktisi Pembelajaran Akuntansi (guru) diperoleh presentase sebesar 89,42\% yang termasuk pada kategori sangat layak. Berdasarkan hasil persentase dari para ahli maka media 
pembelajaran sangat layak untuk dijadikan media pembelajaran Akuntansi.

c. Implementasi penelitian lapangan dilakukan di SMK Negeri 1 Slawi dalam tiga tahap yaitu tahap ujicoba perorangan (3 siswa), tahap ujicoba kelompok kecil (9 siswa), dan tahap penelitian lapangan (64 siswa) yaitu 34 siswa memakai media dan 34 siswa tidak memakai media. Penilaian pada ujicoba perorangan diperoleh persentase $99,58 \%$ dengan kategori sangat layak, penilaian ujicoba kelompok kecil diperoleh persentase 91,67\% dengan kategori sangat layak, dan penilaian pada penelitian lapangan diperoleh persentase $91,80 \%$ dengan kategori sangat layak. Berdasarkan hasil persentase penilaian dari siswa menunjukkan penilaian positif karena semua menunjukkan persentase $\geq$ $70 \%$. Berdasarkan data tersebut dapat disimpulkan bahwa

d. Media Pembelajaran Aplikasi Taksi Berbasis Android dikemas dengan menarik, contoh soal dan soal disampaikan dengan jelas, mendorong rasa ingin tahu dalam belajar Akuntansi, menambah pemahaman tentang Akuntansi, dan menambah motivasi dalam belajar Akuntansi. Media Pembelajaran Aplikasi Taksi Berbasis Android cukup efektif digunakana sebagai media pembelaran Akuntansi, hal ini dapat dilihat berdasarkan rata-rata peningkatan hasil pretest dan posttest sebesar 0,4 atau $40 \%$ pada kelas yang memakai media yaitu kelas $\mathrm{X}$ Akuntansi 4 dengan kategori sedang, dan rata-rata peningkatan hasil pretest dan posttest pada kelas yang tidak memakai media yaitu kelas X Akuntansi 2 adalah 0,3 atau $30 \%$ dengan kategori sedang. Selisih peningkatan hasil pretest dan posttest dari kelas X Akuntansi 4 dan X Akuntansi 2 adalah $10 \%$ di mana peningkatan hasil pretest dan posttest dari kelas X Akuntansi 4 lebih besar daripada peningkatan hasil pretest dan posttest dari kelas X Akuntansi 2, keduanya memiliki kriteria yang sama yaitu $0,3 \leq \mathrm{g}<0,7$ yang termasuk dalam kriteria sedang, sehingga Media Pembelajaran Aplikasi Taksi Berbasis Android pada materi siklus Akuntasi perusahaan jasa cukup efektif digunakan.

\section{Saran}

Berdasarkan penelitian pengembangan yang telah dilakukan, Media Pembelajaran Aplikasi Taksi Berbasis Android tentu masih jauh dari sempurna. Oleh karena itu, beberapa saran pemanfaatan dan pengembangan produk lebih lanjut yang dibutuhkan adalah sebagai berikut:

a. Media Pembelajaran Aplikasi Taksi Berbasis Android sebaiknya digunakan guru dalam kegiatan belajar mengajar sehingga pembelajaran menjadi lebih variative dan menambah antusias belajar siswa.

b. Media Pembelajaran Aplikasi Taksi Berbasis Android sebaiknya digunakan siswa untuk belajar mandiri di rumah dengan memanfaatkan smartphone untuk belajar daripada bermain game atau membuka media sosial yang kurang bermanfaat.

c. Media Pembelajaran Aplikasi Taksi Berbasis Android perlu dikembangkan dari segi soal. Variasi soal kurang beragam karena soal masih tetap tidak berubah walaupun pengguna sudah mengerjakan secara keseluruhan.

d. Untuk penelitian yang selanjutnya, sebaiknya penelitian lapangan dilakukan lebih luas penelitian lapangan tidak hanya dilakukan di satu sekolah dan satu kelas lagi, namun implementasi sebaiknya lebih dari satu kelas atau lebih dari satu sekolah sehingga dapat menghasilkan medipembelajaran yang bisa digunakan secara luas. 
DAFTAR PUSTAKA

IDC (International Data Corporation). (2014). Smartphone OS Market Share, Q2 2016 yang diakses melalui http://www.idc.com/prodserv/smartph oneosmarket-share.jsp pada tanggal 4 Oktober 2016 pukul $10.00 \mathrm{WIB}$

Lee, W.-M. (2011). Beginning Android Application Development. Indiana: Wiley Publishing.

Meltzer, D.E. (2002). "The Relationship Between Matematics Preparation and Conceptual Learning Gains in Physicn: A possible "hidden variable" in diagnostic pretest score". American Journal of physics. Vol.70 No. 12. Hal 1259-1268. (Maret 2016)

Multyaningsih, Endang. (2011). Metodologi Penelitian Terapan Bidang Pendidikan. Bandung: Alfabeta.

Panji Wisnu Wirawan. (2011). Pengembangan Kemampuan ELearning Berbasis Web ke dalam MLearning. Jurnal Universitas Diponegoro. (Vol. 2. No. 4 Hlm 22). http://ejournal.undip.ac.id/index.php/j masif/article/view/2655/2401 pada tanggal 30 Oktober 2016 pukul 22.41 WIB.

Sugiyono. (2012). Metode Penelitian Pendidikan Pendekatan Kuantitatif Kualitatif dan $R \& D$. Bandung:Alfabeta.

Wahono, R.S. (2006).Aspek dan Kriteria Penilaian Media Pembelajaran, diakses dari http://romisatriawahono.net/2006/06/ 21/aspek-dan-kriteria-penilaianmedia-pembelajaran/ pada tanggal 5 November 2016 pukul 16.00 WIB 